\title{
フェンタニル経皮吸収製剤の剥がれ及び使用感に関する検討
}

\author{
栗田かほる, ${ }^{*, a}$ 望月優花, ${ }^{b}$ 国分秀也, ${ }^{c}$ 厚田幸一郎 $b, c$
}

\section{Evaluation of Detachment and Clinical Usability of Transdermal Fentanyl Patches in Healthy Volunteers}

\author{
Kaoru Kurita, ${ }^{*, a}$ Yuka Mochizuki, ${ }^{b}$ Hideya Kokubun, ${ }^{c}$ and Kouichirou Atsuta ${ }^{b, c}$ \\ ${ }^{a}$ Department of Nursing, Kitasato University Hospital; 1-15-1 Kitasato, Minami-ku, Sagamihara, Kanagawa \\ 252-0375, Japan; 'bitasato University School of Pharmacy; 5-9-1 Shirogane, Minato-ku, Tokyo \\ 108-8641, Japan; and 'Department of Pharmacy, Kitasato University Hospital; 1-15-1 \\ Kitasato, Minami-ku, Sagamihara, Kanagawa 252-0375, Japan.
}

(Received March 16, 2015; Accepted July 30, 2015)

\begin{abstract}
The dose of a transdermal fentanyl patch is proportional to its application site area. Therefore, the absorption of fentanyl may decrease if the patch detaches, leading to insufficient analgesia. Sixteen healthy volunteers were enrolled in a study to investigate the appropriate application sites and clinical utility of three transdermal fentanyl patches available in Japan. Three placebos, Fentanyl 1-day (Fentos; Fen), Fentanyl 3-day (Durotep; Dur), and Generic Fentanyl 3-day (HMT) were administered using a crossover study design. The placebos were applied to 11 different sites, including both sides of the upper arm, abdomen, back, thigh, chest, and the middle of the chest. We determined the patch detachment area and incidence of patch-induced itching every $24 \mathrm{~h}$ and evaluated differences between each application site using the Wilcoxon signed-rank test. Significant patch detachment was observed on the abdomen and upper arms with Fen, on the abdomen and chest with Dur, and on the chest with HMT compared with that at other sites $(p<0.005)$. Although no significant difference in itching was observed between regions when administering Fen, itching significantly increased on the chest and back when using Dur and on the abdomen when using HMT as compared with that at other sites $(p<$ $0.05)$. Our results indicate that the three transdermal Fen patches exhibit different adhesive properties and local adverse events, indicating that the application site should be cautiously selected for each patch type.
\end{abstract}

Key words— transdermal fentanyl; detachment; clinical usability

緒言

フェンタニルパッチ（fentanyl patch; FP） は

World Health Organization (WHO) 方式がん疼痛 治療法除痛ラダー1)の三段階に位置する強オピオイ ド鎮痛薬であり，中等度から高度のがん性疼痛に対 して汎用されている．経皮より投与できることから 経口摂取不能ながん患者に有用であり，他のオピオ イド製剤と比較して眠気や便秘が生じ難い2,3)こと から，他のオピオイド鎮痛薬で副作用が出現した患 者に使用できる.

FP は 1 日又は 3 日毎の貼り替えという簡便性か ら，在宅や終末期の緩和医療でも活躍してきた。し

${ }^{a}$ 北里大学病院看護部, ${ }^{b}$ 北里大学薬学部, $c$ 北里大学病 院薬剤部

*e-mail: k.kurita@ kitasato-u.ac.jp
かし，貼付期間内の製剤の剥がれや痒みなどのトラ ブルが起こり，適正に使用できない事例が，しばし ば臨床で報告されている. ${ }^{4)}$ また，FP の投与量は貼 付面積に比例するため, 剥がれが生じると薬物吸収 量が低下し，目的の血中濃度に到達しないことが考 えられる.したがって, 副作用を回避し，十分な鎮 痛効果を得るためには剥がれないことが重要であ る. また，長時間の貼付によって生じる痒みは使用 感の増悪だけでなく，患者が貼付部位を掻いてしま うことにより FP の剥がれを誘発する可能性が考え られる。ゆえに製剤の使用感も貼付剂使用において は考慮する必要がある.

現在，わが国における FP には複数の種類が存在 し，それぞれ材質，形状及び貼付時間が異なるた め, 剥離に影響する要因は製剤毎に異なることが予 想される．また，皮膚の厚みや水分量など，各貼付 
部位の皮膚の状態の違いによっても製剂の粘着力は 変化することが考えられる. FP の使用感と粘着性 については, 大島らの報告5)で検討されているが, 貼付部位毎の検討はなされていない.

そこで今回，わが国で発売されている 1 日型及び 3 日型経皮吸収製剤（フェントス ${ }^{\circledR}$ テープ，デュロ テップ®MT パッチ，フェンタニル 3 日用テープ 「HMT」）のプラセボ製剤を用いて，3 製剤の最適 貼付部位，剥がれに影響する因子及び使用感につい て比較検討した.

\section{方法}

1. 製剤本研究には，主薬成分を含有してい

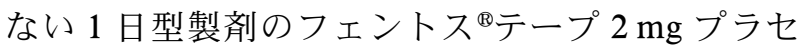
ボ $(31.7 \mathrm{~mm} \times 31.7 \mathrm{~mm}$ ，ロット番号； JB02T，久 光製薬株式会社，以下； Fen)，3 日型製剤のデュロ テップ® MT パッチ $4.2 \mathrm{mg}$ プラセボ $(25.4 \mathrm{~mm} \times$ $41.6 \mathrm{~mm}$ ，ロット番号 ; 0014105-0801281，ヤンセ ンファーマ株式会社, 以下 ; Dur), フェンタニル 3

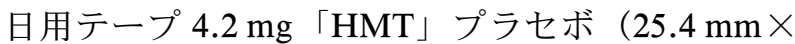
$41.6 \mathrm{~mm}$, ロット番号; M601T, 久光製薬株式会 社，以下；HMT）を使用した。なお，本研究で使 用したプラセボ製剂は実製剂と同様，粘着試験等の 製剂試験を通過し，薬効を除いては実製剤と変わり ない製剂である。

2. 対象健康成人男女 16 名を対象とし, 3 製剂でクロスオーバー試験を行った。ただし，試験 同意取得時に皮膚疾患を診断されているものは除外 した。貼付期間中に腋窩体温で $37^{\circ} \mathrm{C}$ 以上の発熱が ないことを確認し，貼付期間中は入浴禁止（短時間 のシャワーは可), 激しい運動禁止, 飲酒禁止の行 動制限を設けた。貼付期間中に重度の発赤，炎症な どの有害反応が生じた場合は，試験を中止した。

なお，本研究は北里大学医学部・病院倫理委員会 に承認され（承認番号 $\mathrm{C}$ 倫 09-537），「臨床研究に 関する倫理指針」に従って実施した。

\section{3. 試験方法}

3-1. 測定項目試験（貼付）開始直前に，被 験者の年齢，性別，身長，体重，body mass index (BMI)，腋窩体温，体脂肪率，貼付部位の皮下脂 肪厚，皮膚水分量及び皮膚表面温度を測定した。皮 下脂肪厚は各貼付部位 3 回ずつ, 製剂貼付前の皮膚 水分量及び皮膚表面温度は各貼付部位 10 回ずつ測
定し，その平均值を算出した。貼付後 24 時間， 48 時間， 72 時間（Fen は 24 時間のみ）において，製 剤の剥離面積, 掻痒感を確認した。

体脂肪率，皮下脂肪厚，皮膚水分量及び皮膚表面 温度の測定には，オムロン体脂肪計 HBF-306（才 ムロンヘルスケア株式会社)，栄研式皮下脂肪計 (株式会社明興社), モイスチャーチェッカーMY808S (スカラー株式会社), 及び赤外線温度計 サー モチェッカー（株式会社佐藤商事）をそれぞれ使用 した.

3-2. 貼付方法 各貼付部位を清拭し, 適度に 水分を乾燥させた後，プラセボ製剤を貼付した。貼 付時はそれぞれの製剤の添付文書に基づき，貼付後 約 30 秒間手のひらでしっかり押さえ，製剤の縁の 部分が皮膚面に完全に接着するようにした。

貼付部位は左右上腕（上腕三角筋の中央部）, 左 右胸部（鎖骨下 $8 \mathrm{~cm}$ ), 胸骨上（左右胸部の中間 部), 左右腹部 (胁骨下部と臍の中間部), 左右背部 （肩甲骨下部と脊柱の中間部），左右大腿部（大腿前 面の足の付け根と膝の中間部)の全 11 力所とした. 腫れている部位，傷のある部位，体毛の多い部位， 衣類が擦れると予想される部位は避けて貼付した.

試験実施期間は 2011 年及び 2012 年の 4-6月，911 月とし, 気温一定の時期 $\left(15-25^{\circ} \mathrm{C}\right)$ に行った. 貼付期間はそれぞれの添付文書に記載された期間 （Fen は 1 日間，Dur 及び HMT は 3 日間）とした.

3-3. 剥離面積の測定 貼付後 24 時間, 48 時 間及び 72 時間経過時に各貼付部位を肉眼で観察 し，製剤の剥がれた部分をそれぞれ油性のマジック ペン（24 時間後は黒色，48 時間後は赤色， 72 時間 後は青色）でなぞり，剥離状態を写真撮影して記録 した。 Fen は貼付後 24 時間のみ記録した。貼付期 間終了後, 全 11 力所の製剤を皮膚から剥がして用 紙に貼りつけ，用紙をスキャナーで取り込み画像 データ化した。これを用い，貼付後 24 時間， 48 時 間及び 72 時間それぞれについて製剂の全面積に対 する剥離面積の割合（\%）を算出した。この操作に は, アメリカ国立衛生研究所 (National Institutes of Health; NIH）で開発された画像処理ソフト Image J6) を使用した。試験期間中に製剤が完全剥 離した場合は，被験者の該当部位の值は検定から除 外した.

3-4. 使用感調査 貼付後 24 時間， 48 時間及 
び 72 時間（Fen は貼付後 24 時間）において，使用 感として掻痒感を調査した。被験者に 0 ：掻痒感な し, 1 : 掻痒感が少しある, 2 : 掻痒感がある, 3 : 掻痒感がとてもある，の 4 段階の指標を用いて各貼 付部位における掻痒感を評価してもらい，各被験者 の点数から, 各貼付部位の掻痒感平均スコアを算出 した。なお，試験期間中に完全剥離した部分におい ては，その部位のみ評価を行わず，評価から除外し た.

\section{4. 評価方法}

4-1. 製剂内比較 Fen, Dur 及び HMT の各製 剂における各貼付部位の剥離面積（\%）の比較を 行った. 11 力所の貼付部位を 5 領域（上腕，胸部， 腹部，背部，大腿）に分類し，解析には各部位にお ける左右の剥離面積（\%）の平均值を使用した．胸 部のみ胸骨を含めた 3 部位の平均值を用いた。解析 は Fen は貼付後 24 時間のみ, Dur 及び HMT は貼 付後 24 時間， 48 時間， 72 時間のそれぞれについて 行った。製剂内の各貼付部位における掻痒感の比較 は，剥離面積の比較と同様に 5 領域の左右の掻痒感 の平均スコア（胸部のみ 3 部位の平均スコア）を用 いて行った。解析は Fen は貼付 24 時間，Dur 及び HMT は貼付後 24 時間， 48 時間及び 72 時間のそれ ぞれについて行った。

\section{4-2. 製剤間比較 Fen, Dur 及び HMT の各貼} 付部位における製剤間の剥離面積（\%）の比較を 行った。剥離面積（\%）及び掻痒感の平均スコアは 4-1. と同様の方法で算出したものを用いた。剥離面 積（\%）の解析は，貼付部位毎に貼付後 24 時間は Fen, Dur 及び HMT を対象とし，貼付後 48 時間と 72 時間は Dur 及び HMT を対象とした．掻痒感の 解析についても剥離面積（\%) と同様に行った.

4-3. 剥がれに影響する因子の検討 身長, 体 重, 性別, 腋窩体温, 体脂肪率, 皮下脂肪厚, 貼付 前皮膚水分量及び皮膚表面温度を剥がれに影響を及 ぼす因子と予想した。これらの因子について共線性 の診断を行い，独立変数同士の内部相関が高い因子 はどちらかを排除した。その後，ステップワイズ重 回帰分析を行い，各貼付部位における剥離に影響す る因子を抽出した。 1 日型製剤は貼付後 24 時間， 3 日型製剂は貼付後 72 時間の剥離面積を従属変数と し，性別（男性を 0 ，女性を 1 としたダミ一変数を 用いた)，その他の剥がれに影響すると予想される
因子を独立変数とした，重回帰関数のあてはまりの よさから，抽出された因子と剥離面積の関係を評価 した.

5. 統計解析 貼付部位別剥離面積（\%）及び 掻痒感の統計解析には Wilcoxon の符号付き順位和 検定を用いた。 $p$ 值は Bonferroni 法で補正した. 各貼付部位における剥離に影響する因子の抽出に は，ステップワイズ重回帰分析を用いた。

解析には, 統計解析ソフト PASW ${ }^{\circledR}$ Statistics 18 を用いた。有意水準は 0.05 未満とした。

\section{結果}

1. 研究対象者の概要 各製剂貼付開始時の被 験者の基本情報を Table 1 に，皮下脂肪厚，皮膚水 分量, 皮膚表面温度の測定平均值を Table 2 に示し た．試験同意取得時に皮膚疾患を診断されているも のはいなかった。試験対象 16 名のうち, Fen 及び Dur 試験終了時に重度の発赤及び炎症により 1 名が 脱落した。したがって，HMTは 15 名を試験対象 とした.

Dur 及び HMT にて，貼付試験中に製剤の完全剥 離が観察された。D D においては，右胸部の 24 時 間及び 72 時間後各 1 例，左胸部の 24 時間及び 72 時間後各 1 例，胸部中央の 72 時間後に 1 例，右大 腿の 72 時間後に 1 例の完全剥離が観察された.

HMT においては，右大腿の 48 時間後で 1 例，左 大腿の 72 時間後に 2 例の完全剥離が観察された.

2. 製剤内比較 貼付後 24 時間， 48 時間及び 72 時間経過時の各製剂の各貼付部位における使用 プラセボの全面積に対する剥離面積の割合（\%）を Fig. 1 に示した.この結果, Fen では貼付後 24 時 間において上腕一胸部間，胸部-腹部間，腹部一背部 間に有意な差が認められた $(p<0.005)$ 。Durでは 貼付後 24 時間において腹部一大腿間に，貼付後 48 時間において上腕一胸部間に有意な差が認められた $(p<0.005)$. HMT では貼付後 48 時間において胸 部一背部間に有意な差が認められた $(p<0.005)$.

貼付直後，貼付後 24 時間， 48 時間及び 72 時間 経過時における各製剂の掻痒感平均スコアを Fig. 2 に表した。この結果，Fen では貼付直後，貼付後 24 時間においてどの貼付部位間でも有意差は認め られなかった。 Durでは貼付 48 時間において，腹 部-背部間，背部-大腿間，貼付 72 時間後に上腕-胸 
Table 1. Characteristic of Healthy Adult Volunteers

\begin{tabular}{lccc}
\hline \hline & Fen $(n=16)$ & Dur $(n=16)$ & HMT $(n=15)$ \\
\hline Age (years) & $31.3 \pm 6.0(23-42)$ & $31.1 \pm 6.1(23-42)$ & $32.9 \pm 6.59(23-43)$ \\
Gender & 8 & 8 & 7 \\
$\quad$ male & 8 & 8 & 8 \\
$\quad$ female & $164.9 \pm 10.0(150.0-180.0)$ & $164.9 \pm 10.0(150.0-180.0)$ & $164.2 \pm 9.7(150.0-180.0)$ \\
Hight $(\mathrm{cm})$ & $57.7 \pm 13.2(38.5-80.0)$ & $58.1 \pm 13.6(40.0-86.0)$ & $57.6 \pm 13.8(40.0-83.0)$ \\
Weight $(\mathrm{kg})$ & $20.9 \pm 2.9(16.2-27.4)$ & $21.1 \pm 3.1(16.9-29.4)$ & $21.0 \pm 3.2(17.0-28.4)$ \\
BMI & $21.9 \pm 4.3(14.9-30.2)$ & $22.4 \pm 4.4(16.0-29.5)$ & $23.3 \pm 5.0(13.9-31.8)$ \\
Body fat $(\%)$ & $36.3 \pm 0.3(35.7-36.8)$ & $36.3 \pm 0.2(35.8-36.8)$ & $36.4 \pm 0.5(35.5-37.2)$ \\
Body temperature $\left({ }^{\circ} \mathrm{C}\right)$ &
\end{tabular}

Mean \pm S.D. (maximum-minimum).

Table 2. Thickness of Subcutaneous Fat, Skin Moisture, and Skin Temperature in Each Application Site before Application

\begin{tabular}{ccccc}
\hline \hline & & Fen $(n=16)$ & Dur $(n=16)$ & HMT $(n=15)$ \\
\hline & upper arm & $17.33 \pm 4.98$ & $15.78 \pm 4.57$ & $18.64 \pm 5.59$ \\
Thickness of & chest & $7.91 \pm 4.35$ & $6.90 \pm 2.08$ & $7.84 \pm 2.64$ \\
subcutaneous fat & abdomen & $15.64 \pm 6.73$ & $14.64 \pm 5.99$ & $13.71 \pm 5.10$ \\
(mm, mean \pm S.D. $)$ & back & $13.78 \pm 5.13$ & $14.06 \pm 5.19$ & $12.20 \pm 2.42$ \\
& thigh & $19.51 \pm 7.51$ & $17.33 \pm 7.30$ & $17.68 \pm 5.39$ \\
\hline & upper arm & $36.30 \pm 1.84$ & $36.84 \pm 3.98$ & $34.82 \pm 2.25$ \\
Skin moisture & chest & $41.83 \pm 3.22$ & $41.67 \pm 3.72$ & $38.03 \pm 1.71$ \\
$(\%$, mean \pm S.D. $)$ & abdomen & $36.53 \pm 3.68$ & $38.22 \pm 4.45$ & $33.12 \pm 2.25$ \\
& back & $41.53 \pm 4.21$ & $42.04 \pm 3.89$ & $37.54 \pm 1.66$ \\
& thigh & $35.65 \pm 2.81$ & $34.99 \pm 2.43$ & $32.95 \pm 2.98$ \\
\hline Skin temperature & upper arm & $36.32 \pm 0.13$ & $36.37 \pm 0.19$ & $36.30 \pm 0.11$ \\
$\left({ }^{\circ}\right.$ C, mean \pm S.D. $)$ & chest & $36.51 \pm 0.14$ & $36.52 \pm 0.20$ & $36.50 \pm 0.16$ \\
& abdomen & $36.53 \pm 0.16$ & $36.46 \pm 0.18$ & $36.56 \pm 0.24$ \\
& back & $36.41 \pm 0.18$ & $36.39 \pm 0.16$ & $36.50 \pm 0.20$ \\
& thigh & $36.29 \pm 0.08$ & $36.29 \pm 0.09$ & $36.27 \pm 0.09$ \\
\hline
\end{tabular}

部間，上腕一背部間，胸部一大腿間，背部一大腿間に 有意な差が認められた $(p<0.005)$. HMT では貼 付 72 時間後において腹部一大腿間に有意な差が認め られた $(p<0.005)$.

3. 製剤間比較 Fen 及び Durにおいて, HMT での 1 例の脱落例のデー夕を除外し， 3 製剤 とも $n=15$ として統計解析を行った.

各貼付部位における貼付後 24 時間，48 時間及び 72 時間の Fen, Dur 及び HMT の剥離面積（\%） の比較を Fig. 3 に示した. この結果, 貼付後 24 時 間において，上腕及び大腿で Fen-Dur 間，FenHMT 間に有意な差が認められた $(p<0.016)$ 。ま た貼付後 48 時間において大腿以外の部位で DurHMT 間に有意な差が認められた $(p<0.05)$. 貼付 後 72 時間において全部位で Dur-HMT 間に有意な
差が認められた $(p<0.05)$.

各貼付部位における貼付後 24 時間，48 時間及び 72 時間の Fen, Dur 及び HMT の掻痒感平均スコ アの比較を Fig. 4 に示した。この結果，3 製剤にお ける貼付後 24 時間においてはどの貼付部位でも有 意差を認めなかつた。貼付後 48 時間において胸部 及び腹部で Dur-HMT 間に有意な差が認められた $(p<0.05)$. 貼付後 72 時間において腹部で DurHMT 間に有意な差が認められた $(p<0.05)$.

4. 剥がれに影響を及ばす因子の抽出 共線性 の診断を行った結果，すべての領域において身長と 体重の間に相関が認められたため，今回は体重を因 子として残し，身長は除外した。

各領域のステップワイズ重回帰分析の結果を Table 3 に示した. Fen では, 胸部以外の領域であて 

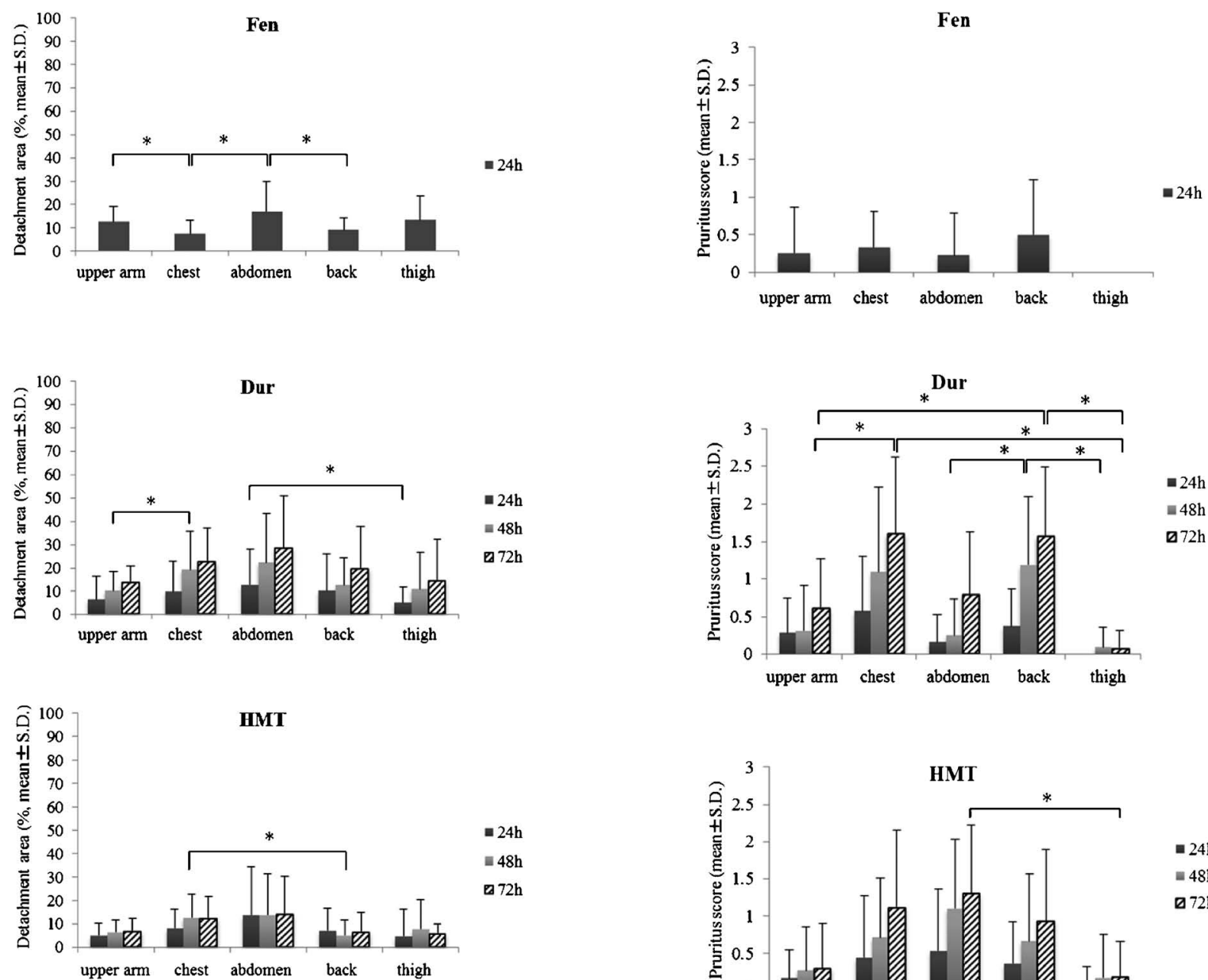

Fig. 1. Peeled Off Area of Each Application Site in Fen, Dur, and HMT

Fen, Dur: $n=16$, HMT: $n=15,{ }^{*} p<0.005$.

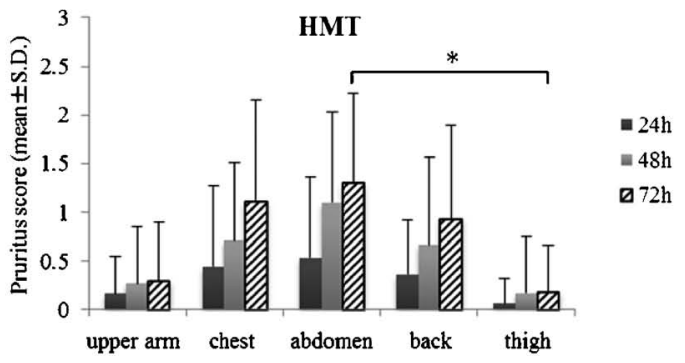

Fig. 2. Pruritus Score of Each Application Site in Fen, Dur, and HMT

Fen, Dur: $n=16$, HMT: $n=15,{ }^{*} p<0.005$.

はまりのよい重回帰関数が得られ $(p<0.05)$, 特に 上腕，背部及び大腿であてはまりのよい重回帰関数 が得られた（それぞれ $\mathrm{R}^{2}=0.447, \mathrm{R}^{2}=0.760, \mathrm{R}^{2}=$ 0.508)。剥離に影響を及ぼす有意な因子として，上 腕，大腿では体重及び皮下脂肪厚，腹部では性別及 び体重，背部では体重が挙げられた $(p<0.05)$ 。皮 下脂肪厚に関しては領域によって標準化係数 $\beta$ の 符号が異なり，上腕では皮下脂肪が薄いほど剥がれ 易く，大腿では皮下脂肪が厚いほど剥がれ易い結果 となった．Durでは，全領域で有意な重回帰関数が 得られた $(p<0.05)$ 。特に上腕，胸部及び大腿であ てはまりのよい重回帰関数が得られた（それぞれ $\left.\mathrm{R}^{2}=0.571, \mathrm{R}^{2}=0.469, \mathrm{R}^{2}=0.565\right)$ 。剥離に影響を及 ぼす有意な因子として，上腕では体脂肪率及び皮膚 水分量，胸部では体重及び皮膚水分量，腹部及び背 部では皮下脂肪厚，大腿では性別及び体脂肪率が抽

出された $(p<0.05)$. 標準化係数 $\beta$ の值より皮膚 水分量が高い人，体脂肪率が高い人，体重が重い 人，皮下脂肪が厚い人，男性の場合に剥がれ易い結 果となった，HMT では，全領域で有意な重回帰関 数が得られ（ $p<0.05 ）$, 特に腹部であてはまりのよ い重回帰関数が得られた $\left(\mathrm{R}^{2}=0.547\right)$ 。剥離に影響 を及ぼす因子として，上腕では皮下脂肪厚，胸部で は性別及び皮膚温，腹部では皮膚水分量，体温及び 体脂肪，背部では性別，大腿では皮下脂肪厚が抽出 された $(p<0.05)$ ．標準化係数 $\beta$ の值より，皮下 脂肪が厚い人，体温が高い人，皮膚温が低い人，皮 膚水分量が高い人，体脂肪率が高い人，男性の場合 に剥がれ易い結果となった。 

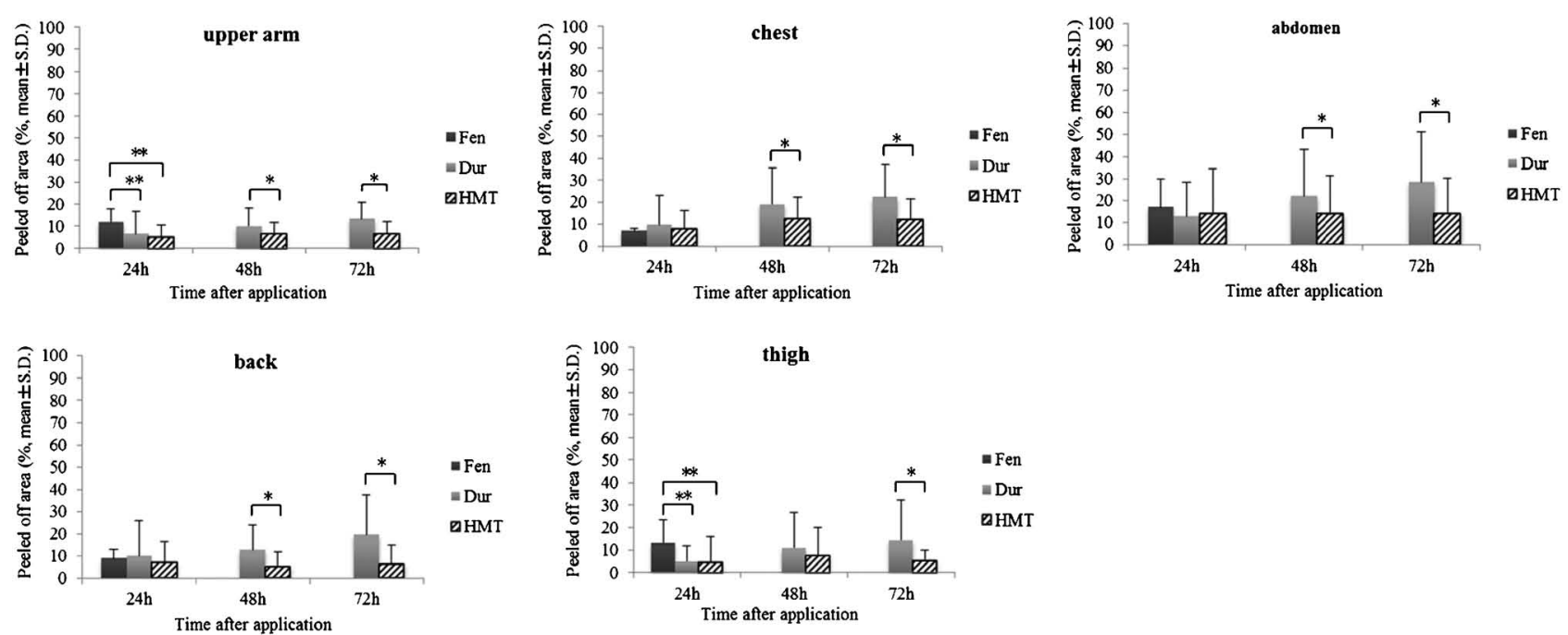

Fig. 3. Peeled Off Area of Fen, Dur, and HMT in Each Application Site Fen, Dur: $n=16$, HMT: $n=15,24 \mathrm{~h}:{ }^{*} p<0.016,48 \mathrm{~h}, 72 \mathrm{~h}:{ }^{*} p<0.05$.
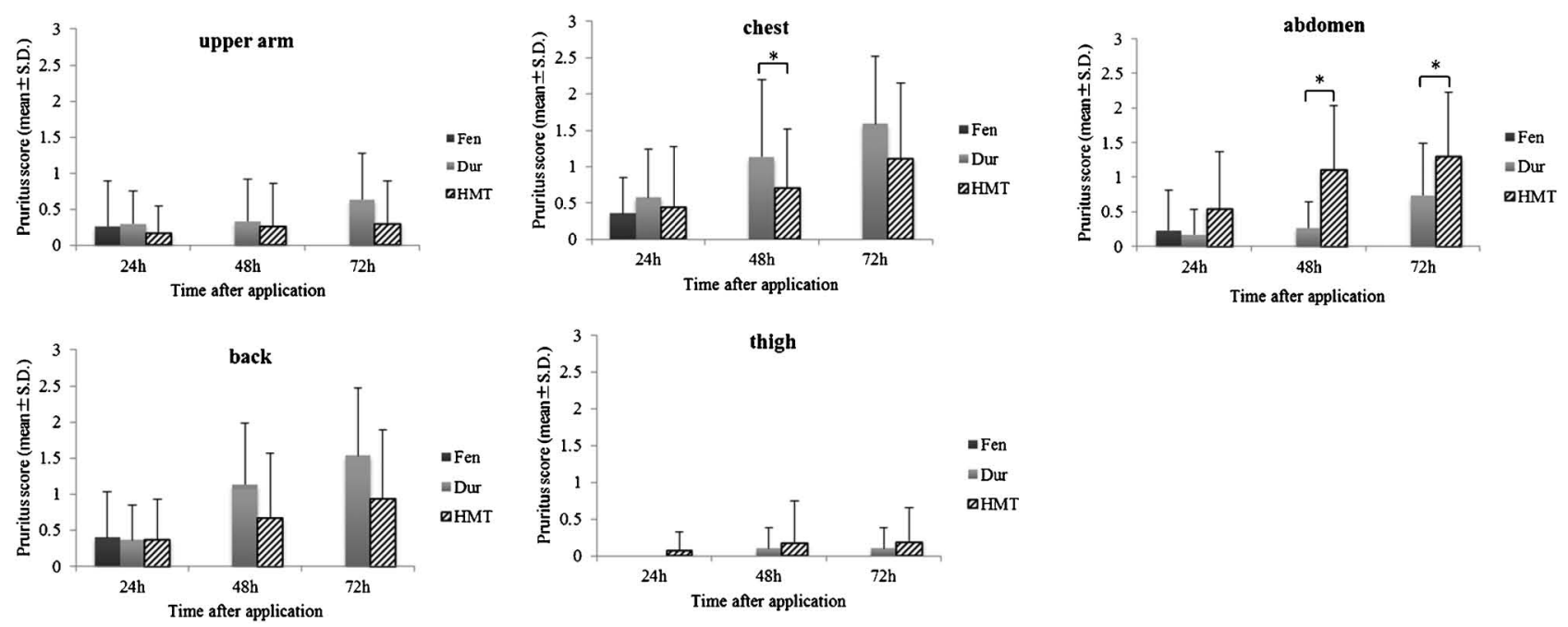

Fig. 4. Pruritus Score of Fen, Dur, and HMT in Each Application Site Fen, Dur: $n=16$, HMT: $n=15,48 \mathrm{~h}, 72 \mathrm{~h}:{ }^{*} p<0.05$.

\section{考察}

現在，FPはがん性疼痛に対し貼付剂という簡便 性から多くの患者に汎用されているが，皮膚の状態 によって血中濃度が大きく変動することが知られて いる，例えば， Suneel らの報告7)によると，FP は $37^{\circ} \mathrm{C}$ から $40^{\circ} \mathrm{C}$ の体温上昇で貼付後 36 時間におい て血中濃度が約 $25 \%$ 上昇すると予測している。ま た，貼付部位の皮膚加温により血中濃度が約 2 倍上 昇したとの報告がある. ${ }^{8}$ わが国においても，製薬 企業からの「使用上の注意」のお知らせにおいて, FP 使用患者で入浴や発熱に起因する血中濃度上昇
での死亡例が報告されている. U.S. Food and Drug Administration （FDA，米国食品医薬品局）では 2007 年 12 月に 2 度目の安全性警告を発行しており, FP はがん性疼痛に有用である一方, 不適切及び 誤つた使用によって生命を驚かす可能性があること が懸念されている。 さらに，Heiskanen らの報告9) によると，がん悪液質患者の皮膚状態ではフェンタ ニルの吸収率が低下することを示唆している。 また, in vitro の研究において, 乾燥皮膚では FP の吸収 量が低下したとの報告 ${ }^{10)}$ があり, 皮膚の状態も FP の血中濃度に深く関与すると考えられる。また，貼 付剤の問題点として，「剥がれ」がある。製剤と皮 
Table 3. The Factor Affecting Transdermal Fentanyl Peeled Off by Stepwise Multiple Regression

(Fen)

\begin{tabular}{|c|c|c|c|c|c|}
\hline \multirow{2}{*}{$\begin{array}{l}\text { Application } \\
\text { site }\end{array}$} & \multirow{2}{*}{ Factor } & \multicolumn{2}{|c|}{ Fitness of multiple regression function } & \multicolumn{2}{|c|}{ Multiple regression coefficient } \\
\hline & & $\mathrm{R}^{2}$ & $p$ & $\beta$ & $p$ \\
\hline \multirow{2}{*}{$\begin{array}{l}\text { Upper arm } \\
(n=32)\end{array}$} & Weight & \multirow{2}{*}{0.447} & \multirow{2}{*}{0.000} & 0.504 & 0.001 \\
\hline & Thickness of subcutaneous fat & & & -0.544 & 0.000 \\
\hline \multirow{2}{*}{$\begin{array}{c}\text { Abdomen } \\
(n=32)\end{array}$} & Gender & \multirow{2}{*}{0.316} & \multirow{2}{*}{0.002} & 0.517 & 0.028 \\
\hline & Weight & & & 0.862 & 0.001 \\
\hline $\begin{array}{c}\text { Back } \\
(n=32)\end{array}$ & Weight & 0.760 & 0.000 & 0.876 & 0.000 \\
\hline \multirow{2}{*}{$\begin{array}{c}\text { Thigh } \\
(n=32)\end{array}$} & Weight & \multirow{2}{*}{0.508} & \multirow{2}{*}{0.000} & 0.600 & 0.000 \\
\hline & Thickness of subcutaneous fat & & & 0.392 & 0.004 \\
\hline
\end{tabular}

Upper arm: Peeled off area $=10.402+0.248 \times($ Weight $)-0.705 \times$ (Thickness of subcutaneous fat), Abdomen: Peeled off area $=-43.272+13.420 \times($ Gender $($ male; 0, female; 1$))+0.950 \times($ Weight $)$, Back: Peeled off area $=0.155 \times($ Weight $)$, Thigh: Peeled off area $=-24.806+0.477 \times($ Weight $)+0.546 \times($ Thickness of subcutaneous fat).

(Dur)

\begin{tabular}{|c|c|c|c|c|c|}
\hline \multirow{2}{*}{$\begin{array}{l}\text { Application } \\
\text { site }\end{array}$} & \multirow{2}{*}{ Factor } & \multicolumn{2}{|c|}{ Fitness of multiple regression function } & \multicolumn{2}{|c|}{ Multiple regression coefficien } \\
\hline & & $\mathrm{R}^{2}$ & $p$ & $\beta$ & $p$ \\
\hline \multirow{2}{*}{$\begin{array}{l}\text { Upper arm } \\
(n=32)\end{array}$} & Body fat & \multirow{2}{*}{0.571} & \multirow{2}{*}{0.000} & 0.541 & 0.000 \\
\hline & Skin moisture & & & 0.378 & 0.006 \\
\hline \multirow{2}{*}{$\begin{array}{l}\text { Chest } \\
(n=43)\end{array}$} & Weight & \multirow{2}{*}{0.469} & \multirow{2}{*}{0.000} & 0.394 & 0.019 \\
\hline & Skin moisture & & & 0.430 & 0.011 \\
\hline $\begin{array}{c}\text { Abdomen } \\
(n=32)\end{array}$ & Thickness of subcutaneous fat & 0.276 & 0.003 & 0.525 & 0.003 \\
\hline $\begin{array}{c}\text { Back } \\
(n=32)\end{array}$ & Thickness of subcutaneous fat & 0.153 & 0.032 & 0.392 & 0.032 \\
\hline \multirow{2}{*}{$\begin{array}{c}\text { Thigh } \\
(n=31)\end{array}$} & Gender & \multirow{2}{*}{0.565} & \multirow{2}{*}{0.000} & -0.437 & 0.003 \\
\hline & Body fat & & & 0.740 & 0.000 \\
\hline
\end{tabular}

Upper arm: Peeled off area $=-33.669+0.929 \times($ Body fat $)+0.713 \times($ Thickness of subcutaneous fat $)$, Chest: Peeled off area $=-77.752+0.469 \times($ Weight $)+$ $1.901 \times($ Skin moisture $)$, Abdomen: Peeled off area $=-4.251+2.181 \times($ Thickness of subcutaneous fat $)$, Back: Peeled off area $=-4.433+1.734 \times($ Thickness of subcutaneous fat), Thigh: Peeled off area $=-48.105-15.207 \times($ Gender (male; 0, female; 1$))+3.153 \times($ Body fat $)$.

(HMT)

\begin{tabular}{|c|c|c|c|c|c|}
\hline \multirow{2}{*}{$\begin{array}{l}\text { Application } \\
\text { site }\end{array}$} & \multirow{2}{*}{ Factor } & \multicolumn{2}{|c|}{ Fitness of multiple regression function } & \multicolumn{2}{|c|}{ Multiple regression coefficient } \\
\hline & & $\mathrm{R}^{2}$ & $p$ & $\beta$ & $p$ \\
\hline $\begin{array}{l}\text { Upper arm } \\
(n=30)\end{array}$ & Thickness of subcutaneous fat & 0.141 & 0.041 & 0.376 & 0.041 \\
\hline \multirow{2}{*}{$\begin{array}{l}\text { Chest } \\
(n=45)\end{array}$} & Gender & \multirow{2}{*}{0.288} & \multirow{2}{*}{0.001} & -0.325 & 0.032 \\
\hline & Skin temperature & & & -0.303 & 0.045 \\
\hline \multirow{3}{*}{$\begin{array}{l}\text { Abdomen } \\
(n=30)\end{array}$} & Skin moisture & \multirow{3}{*}{0.547} & \multirow{3}{*}{0.000} & 0.672 & 0.000 \\
\hline & Body temperature & & & 0.490 & 0.002 \\
\hline & Body fat & & & 0.400 & 0.006 \\
\hline $\begin{array}{c}\text { Back } \\
(n=30)\end{array}$ & Gender & 0.189 & 0.016 & -0.435 & 0.016 \\
\hline $\begin{array}{c}\text { Thigh } \\
(n=28)\end{array}$ & Thickness of subcutaneous fat & 0.132 & 0.048 & 0.364 & 0.048 \\
\hline
\end{tabular}

Upper arm: Peeled off area $=-0.426+0.377 \times($ Thickness of subcutaneous fat $)$, Chest: Peeled off area $=667.007-6.038 \times($ Gender $(\mathrm{male} ; 0$, female; 1$))-$ $17.688 \times($ Skin temperature) , Abdomen: Peeled off area $=-796.07+5.013 \times($ Skin moisture $)+16.818 \times($ Body temperature $)+1.371 \times($ Body fat $)$, Back: Peeled off area $=17.434-7.284 \times($ Gender (male; 0 , female; 1$))$, Thigh: Peeled off area $=-0.075+0.317 \times($ Thickness of subcutaneous fat $)$. 
Table 4. Conclusion of Peeled Off and Pruritus in Transdermal Fentanyl

\begin{tabular}{|c|c|c|c|c|}
\hline & $\begin{array}{c}\text { The site which is easy } \\
\text { to peel off }\end{array}$ & $\begin{array}{l}\text { The site which is hard } \\
\text { to peel off }\end{array}$ & $\begin{array}{l}\text { The site where } \\
\text { itch is strong in }\end{array}$ & $\begin{array}{l}\text { The site which } \\
\text { itch has weak }\end{array}$ \\
\hline Fen & $\begin{array}{l}\text { Abdomen }(16.93 \pm 12.89) \\
\text { Upper arm }(12.51 \pm 6.45)\end{array}$ & $\begin{array}{l}\text { Back }(9.08 \pm 5.23) \\
\text { Chest }(7.43 \pm 5.83)\end{array}$ & - & - \\
\hline Dur & $\begin{array}{l}\text { Abdomen }(28.38 \pm 22.78) \\
\text { Chest }(22.39 \pm 14.77)\end{array}$ & $\begin{array}{c}\text { Upper arm }(13.40 \pm 7.56) \\
\text { Thigh }(14.21 \pm 18.09)\end{array}$ & $\begin{array}{l}\text { Chest } \\
\text { Back }\end{array}$ & $\begin{array}{l}\text { Upper arm } \\
\text { Abdomen } \\
\text { Thigh }\end{array}$ \\
\hline HMT & $\begin{array}{l}\text { Abdomen }(14.03 \pm 16.25) \\
\text { Chest }(12.31 \pm 9.22)\end{array}$ & $\begin{array}{c}\text { Upper arm }(6.61 \pm 5.6) \\
\text { Back }(6.27 \pm 8.62) \\
\text { Thigh }(5.62 \pm 4.37)\end{array}$ & $\begin{array}{c}\text { Chest } \\
\text { Abdomen } \\
\text { Back }\end{array}$ & $\begin{array}{l}\text { Upper arm } \\
\text { Thigh }\end{array}$ \\
\hline
\end{tabular}

( ); Mean of peeled off area (\%), Fen: 24 h-value, Dur and HMT: 72 h-value.

膚との接着面積は薬剂の吸収量に関与するため, 剥 がれはバイオアベイラビリティ低下を引き起こすこ とが考えられる。これにより，十分な鎮痛効果が得 られない可能性があり, FP の剥がれは鎮痛効果を 妨げる重要な因子であると考えられる，さらに，貼 付剂の長時間の使用は, 皮膚掻痒感など皮膚トラブ ルを起こすことが予想され，患者の QOL に影響を 及ぼすことが考えられる。そこで，今回は FP の剥 がれと使用感に注目し，製剤毎の最適貼付部位，剥 がれに影響する因子，及び使用感について検討を 行った.

まず，各製剤における剥離面積の検討を行った。 各貼付部位間の比較において, Dur では胸部におい て完全剥離例が 3 例みられ, 被験者によってばらつ きが大きく個人差があると言えた。胸部は他の部位 と比べて皮膚水分量が多いことが特徵であり，それ が剥がれの一因であると推測された。また，Durと HMT は同じ製剂型（長方形）11,12) であり，長時間 の貼付によって体動の影響を受けるため, 剥がれ易 い部位として胸部が共通していたと考えられた。一 方で，Fen は正方形であり ${ }^{13)}$ 製剂が硬くできている ため, 腹部などの動きが大きく伸縮し易い部分や上 腕などの湾曲している部分で剥がれ易くなつたと考 えられた，次に，製剤間の比較を行った結果，上腕 及び大腿部では，貼付後 24 時間において Fen が Dur 及び HMT と比較して有意に剥離面積が大き かった。このことは，上述したように Fen は正方 形であり，製剂が硬くできているため，腹部などの 動きが大きい部分や上腕などの湾曲している部分で の剥がれが大きくなったと考えられた．また，全部 位において Dur は HMT と比較して有意に剥離面
積が大きかった，大島らの報告5)によると，FP は 使用する基材によって粘着力が異なることを示唆し ており，製剤自体の基材の違いから HMT は Dur に比べて粘着力が強いと考えられた.

次に, 各製剂における掻痒感の検討を行った。 Fen は短時間の貼付であり, 物理的な刺激が比較的 少ないために, 各貼付部位での掻痒感の差はないと 考えられた．Dur は長時間の貼付であるため，物理 的な刺激が係わると考えられ，特に貼付期間中の発 汗によって生じた製剤と皮膚の間に貯留した水分が 掻痒感を増幅させたと考えられた。これは, Table 2 において胸部と背部の皮膚水分量が他の部位と比 較して高いことからも推測された。 さらに，Dur は 製剤の厚みが $100 \mu \mathrm{m}$ であり, ${ }^{11)} \mathrm{HMT}$ と比較して 硬いために皮膚の薄い胸部では貼付した製剤が刺激 となり，掻痒感が強かったと考えられた。 大島らの 報告5)においても，われわれと同様の結果を示して おり，Dur は他の製剤よりも痒夕が多い傾向を示し ている.

次に，ステップワイズ重回帰分析を用いて，剥が れに影響する因子の検討を行った。Fenでは，体 重, 皮下脂肪厚及び性別が抽出された。特に体重は 上腕，腹部，背部及び大腿で抽出された重要な因子 であり，体重が重い肥満体質の人ほざ Fen は剥が れ易いと考えられた。 Durでは，体脂肪率，皮膚水 分量, 体重, 皮下脂肪厚, 性別が抽出された. HMT では, 皮下脂肪厚, 性別, 皮膚温, 皮膚水分 量, 体温, 体脂肪率, 性別, 皮下脂肪厚が抽出さ れ，部位によって因子は様々であった，体重が重い 人は体脂肪率及び皮下脂肪厚が大きいと推測される ため,これらの因子が抽出されたと考えられた。性 
別の因子抽出について, Fen の腹部で女性が剥がれ 易いのは，女性は男性と比較して皮下脂肪が比較的 厚く，体動の影響が大きいためと考えられた．また，

Dur の大腿，HMT の胸部及び背部で男性が剥がれ 易いのは，発汗の影響が考えられた。男性は女性と 比較して発汗量が多いため, ${ }^{14)}$ 男性の因子抽出は発 汗量に起因すると推測された。

本研究により，FP は貼付部位によって剥離面積 や掻痒感が異なることが示唆され，剥がれや掻痒感 を考慮した貼付部位の選択が必要であると考えられ た。最適貼付部位の検討では，Fen は胸部及び背部 が剥がれ難く，掻痒感も少ないことから貼付部位と して適していると考えられ，上腕及び大腿は貼付部 位として適さないと考えられた。また，Dur及び HMT は大腿及び上腕が貼付部位として適している と考えられ，胸部及び背部は貼付部位として適さな いと考えられた（Table 4)。しかし，睡眠を含めた 患者の日常生活動作，体質，病態などは様々であ り，すべての患者に今回の結果が適合するわけでは なく, 本研究の限界である。本研究の結果を参考 に，臨床使用においては，日常生活動作や皮膚の状 態を考慮し，患者一人ひとりに合わせた製剤及び貼 付部位の選択を行い，製剤の適正使用に努めること が望ましいと考えられた。

謝辞 本研究の統計解析について，ご助言を頂 きました北里大学病院薬学部臨床統計学の高橋史朗 先生，爽秋会クリニカルサイエンス研究所の瀬戸山 修先生に御礼申し上げます。

利益相反＼cjkstart開示すべき利益相反はない.

\section{REFERENCES}

1) World Health Organization (WHO), "Cancer Pain Relief," WHO, Geneva, 1986.

2) Ahmedzai S., Brooks D., J. Pain Symptom Manage., 13, 254-261 (1997).

3) Hunt R., Fazekas B., Thorne D., Brooksbank M., J. Pain Symptom Manage., 18, 111-119 (1999) .

4) Hattori S., Sano H., Tanaka K., Morino R., Kanazawa M., Arisaka R., Yokota M., Shirasawa M., J. New Rem. \& Clin., 59, 14251436 (2010).

5) Oshima S., Hazama Y., Hosoya O., Nagashima K., Tanaka T., Sano M., Ohta S., Yasuno N., Juni K., Jpn. J. Pharm. Palliat. Care Sci., 5, 7-13 (2012).

6) Image J, Image Analysis Software, National Institutes of Health (NIH).

7) Gupta S. K., Southam M., Gale R., Hwang S. S., J. Pain Symptom Manage., 7, S17-S26 (1992).

8) Ashburn M. A., Ogden L. L., Zhang J., Love G., Basta S. V., J. Pain, 4, 291-297 (2003).

9) Heiskanen T., Mätzke S., Haakana S., Gergov M., Vuori E., Kalso E., Pain, 144, 218-222 (1999).

10) Ooi K., Mitani N., Numajiri S., Morimoto Y., Jpn. Pharmacol. Ther., 36, 589-592 (2008) .

11) Durotep ${ }^{\circledR}$ MT Patch Interview Form, Janssen Pharmaceutical K.K., 2011.

12) Fentanyl 3 days tape (HMT) Interview Form, Hisamitsu Pharmaceutical Co., Inc., 2012.

13) Fentos ${ }^{\circledR}$ tape Interview Form, Hisamitsu Pharmaceutical Co., Inc., 2011.

14) Yoshimaru K., Nakazato Y., Tamura N., Araki N., The Autonomic Nervous System, 47, 138-143 (2010). 